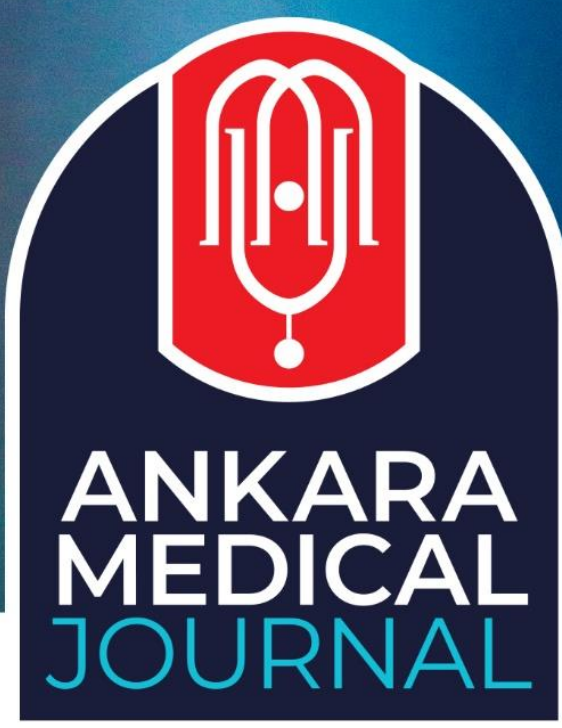

Case Report

Ankara Med J, 2020;(4):1082-1087 // (6i) 10.5505/amj.2020.48243

\title{
PREGNANCY CARE IN FAMILY MEDICINE: FROM A PAINFUL LYMPHADENOPATHY TO A RARE NON- HODGKIN'S LYMPHOMA CASE
}

\section{AİLE HEKIMLİĞİNDE GEBELİK İZLEMLERİ: AĞRILI LENFADENOPATİDEN NADİR HODGKİN DIŞI LENFOMA OLGUSUNA}

(D) Beyza Gökçek ${ }^{1}$, (D) Hümeyra Aslaner ${ }^{2}$, (D) Ali Ramazan Benli ${ }^{3}$

${ }^{1}$ Kayseri Provincial Health Directorate

${ }^{2}$ Kayseri City Hospital

${ }^{3}$ Karabük University

Yazışma Adresi / Correspondence:

Uzm. Dr. Beyza Gökçek (e-mail: beyzaozgun@gmail.com)

Geliş Tarihi (Submitted): 13.07.2020 // Kabul Tarihi (Accepted): 09.11.2020

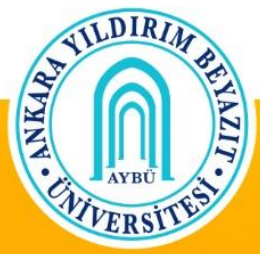

Ankara YIldırım Beyazıt University Faculty of Medicine

Department of Family Medicine 


\title{
Öz
}

32 yaşında, 17 haftalık gebe hasta, üst solunum yolu enfeksiyonu sonrasında boynunun sağ tarafında ağrılı bir kitle fark edip aile hekimliği polikliniğine başvurdu. Fizik muayenede vitalleri stabildi. Farinksinin hiperemik olduğu, sağ servikal bölgede en büyüğü $1 \mathrm{~cm}$ olan birkaç adet lastik kıvamında, sert, fikse, ağrılı lenfadenopatisi olduğu saptandı. Hastaya aile hekimi tarafından üst solunum yolu enfeksiyonu tanısı ile ampirik antibioterapi başlanıp kontrole çağrıldı. Lenf bezlerindeki hızlı büyüme ve boyutlarının $1 \mathrm{~cm}$ 'in üzerinde olması nedeni ile malignite ön tanısı ile kulak burun boğaz polikliniğine sevk edildi. Alınan eksizyonel biyopsi sonucunda Diffüz Büyük B Hücreli Lenfoma tanısı aldı. Kemoterapi planlanan hastaya gebelik terminasyonu önerildi ancak hasta reddetti. Gebeliğin 32. haftasında fetal distres nedeni ile $1500 \mathrm{gr} \mathrm{kız} \mathrm{bebeğin} \mathrm{sezaryen} \mathrm{ile} \mathrm{canlı} \mathrm{olarak} \mathrm{doğumu}$ gerçekleştirildi. Gebelikle bağlantılı olması ve seyrek görülmesi, malignite gibi hayati bir hastalıkta aile hekiminin erken teşhiste rol alması nedeniyle olgunun literatür eşliğinde sunulması uygun görülmüştür.

Anahtar Kelimeler: Gebelik, lenfadenopati, lenfoma.

\begin{abstract}
A 32-year-old, 17-week pregnant patient visited her family physician because of painful lymphadenopathy on the right side of her neck after an upper respiratory tract infection. On physical examination, her vital signs were stable. A few elastic, firm, fixed, and painful lymphadenopathies, the largest of which was $1 \mathrm{~cm}$ were detected in the right cervical region, and the pharynx of the patient was hyperemic. Empirical antibiotherapy treatment was initiated by the family physician with the diagnosis of upper respiratory tract infection and the patient was called for control follow-up. Due to the rapid growth of lymph nodes and their size over $1 \mathrm{~cm}$, she was referred to the otorhinolaryngology outpatient clinic with a preliminary diagnosis of malignancy. She was diagnosed with Diffuse Large B Cell Lymphoma. Pregnancy termination was recommended to the patient whose chemotherapy was scheduled, but the patient refused. At the $32^{\text {nd }}$ week of pregnancy, the pregnancy was terminated due to fetal distress and a 1500-gram live baby girl was born. Since it is associated with pregnancy and rare, and that the family physician plays a role in early diagnosis of a important disease such as malignancy, it is deemed appropriate to present the case with literature.

Keywords: Pregnancy, lymphoma, lymphadenopathy.
\end{abstract}




\section{Introduction}

Lymphoma is a general term used to describe the malignant lymph tumor. Lymphomas are the tumors that start in lymphocytes ( $\mathrm{T}$ or B cells) or natural killer (NK) cells that are among immune system cells. ${ }^{1-2}$ Although its distribution differs according to geographical regions and etiological factors Non-Hodgkin's lymphoma consists of approximately $75 \%$ of all lymphomas and Hodgkin's lymphoma consists of $25 \%$ when generally evaluated. ${ }^{2}$

Diagnosis of Non-Hodgkin's Lymphoma (NHL) accounts for about $4 \%$ of new cancer cases. Prognosis is bad in high-grade NHL and the expected lifetime is quite short. NHL is rarely seen during pregnancy while Hodgkin's lymphoma is more common during pregnancy. ${ }^{3}$ Lymphomas in pregnancy are generally high-grade and involve the most stimulated organs during pregnancy such as the breast, ovary, and uterus. In the study performed by Beksac et al. between 1937 and 1980, 75 lymphoma cases in pregnancy were reported. ${ }^{4}$ The disease is diagnosed late in pregnancy and its course is aggressive. However, it was reported that healthy fullterm infants were born as well. The clinical course of lymphoma is more stable during pregnancy and becomes faster after delivery. ${ }^{5}$

In our case, as the family physician realized lymphadenopathy as a result of general physical examination and followed up with the patient early diagnosis was established. This case report points out a rare co-existence of pregnancy and NHL and reveals how effective the role of family physicians is in early diagnosis of a disease. Our case was approved to be presented as the patient in our case report had a lymphadenopathy in her neck during the $17^{\text {th }}$ week of pregnancy and the mass grew fast, and the diagnosis of NHL is rare during pregnancy. Informed patient consent was obtained for this case report.

\section{Case}

\section{Medical Background}

A 32-year old, 17-week pregnant female patient visited her family physician as she had a sore throat. The patient realized a painful and nut-sized mass which she had had for 15 days. She had 4 gravities, 3 parities, and 2 alive healthy children. One of her babies became exitus at the age of 1 with a preliminary diagnosis of metabolic disease. In her medical history, she had allergic asthma and in her family history, her father had diabetes mellitus and her mother had allergic asthma and hypertension. 


\section{Physical Examination}

Vital findings of the patient were as follows: body temperature: $38^{\circ} \mathrm{C}$, arterial blood pressure: $120 / 80 \mathrm{~mm} / \mathrm{Hg}$, pulse: 75 beats/min. The family physician detected a few elastic, firm, fixed, and painful lymphadenopathies, the largest of which was $1 \mathrm{~cm}$, in the right cervical region, and the pharynx of the patient was hyperemic. Her respiratory system and abdominal examinations were normal. She had no sweating, fever, and loss of weight complaints in detailed anamnesis during admission, but she had severe itching. With a diagnosis of upper respiratory tract infection, the family physician initiated an empiric antibiotherapy for the patient and called her for control follow-up. Previous examinations showed pregnancy and pregnancy care follow-ups of the patient were regularly done. In that period, her system examinations were reported as normal.

\section{Laboratory and Pathological Results}

Lab results were as follows: $\mathrm{Hb}: 12.10 \mathrm{~g} / \mathrm{dL}, \mathrm{WBC}: 5500 \mathrm{~mm}^{3}$, PLT: 300,000mm³ ${ }^{3}$ RDW: $14.5 \%$, NE\%: 66\%, LY\%: 22\%, ALT: $30 \mathrm{u} / \mathrm{L}, \mathrm{AST}: 33 \mathrm{u} / \mathrm{L}, \mathrm{GGT}: 33 \mathrm{u} / \mathrm{L}$, and Cr: $0.8 \mathrm{mg} / \mathrm{dL}$. Complete urine test results were as follows: Color: Pale yellow, Transparency: Clear, Density: 1010 g/mL, pH: 6.5, Protein, Glucose and Ketone: Negative, and WBC: $1 / \mathrm{HPF}$.

When the patient came for her control follow-up after antibiotherapy the largest lymphadenopathy in the cervical chain was $2 \mathrm{~cm}$ and palpable. Due to the rapid growth in lymph nodes and their sizes greater than 1 $\mathrm{cm}$ the patient was referred to an otorhinolaryngology outpatient clinic. The family physician encouraged the patient to consult a psychiatrist as the patient was pregnant and had lost her baby before and her findings indicated a malignant disease. The patient was examined in the otorhinolaryngology outpatient clinic and cervical ultrasonography was decided. Her cervical ultrasonography showed findings compatible with malignancy and a biopsy was scheduled. Excisional biopsy and pathology results were reported as follows: "Tissue units belonging to the diffuse lymph node that lost its normal structure and diffuse cells were in size 34 times greater than mature lymphocyte and most of them were in immunoblastic morphology with central nucleolus. Pleomorphism and marginal adipose tissue and muscle tissue invasion were monitored. These cells were diffusely stained with CD20 and PAX6, positively stained with BCL-2 and BCL-6, and negatively stained with MUM 1. The positivity rate of C-MYC was $10-20 \%$ and Ki67 proliferation index was $80 \%$." The patient was diagnosed with Diffuse Large B Cell Lymphoma.

\section{Medical Follow-up}

Pregnancy termination was recommended, but the patient who was also in contact with the family physician refused the termination. It was decided with the physician not to terminate the pregnancy so long as it was not life-threatening. Chemotherapy was scheduled for the patient. During chemotherapy, preterm labor started at 
the $20^{\text {th }}$ week of pregnancy and tocolytic therapy was used. At the end of the fifth cycle of chemotherapy, the pregnancy was terminated with cesarean due to fetal distress at the gestational age of 32 weeks and 2 days. A 1500 -gram live baby girl was born. APGAR score of the baby was 7 in the $1^{\text {st }}$ minute and 8 in the $5^{\text {th }}$ and $10^{\text {th }}$ minutes. The general condition of the baby deteriorated during her follow-ups, necrotizing enterocolitis and skeptic shock developed and the baby became exitus when she was 15 days old. One cycle of r-chop and 5 cycles of da-epoch-r chemotherapy was completed in 22 weeks. The family physician got in contact with the patient when she was receiving chemotherapy, got information about her condition, and psychosocially supported her. He also kept his support during her delivery and follow-ups when complications developed after delivery. After therapy of the patient ended she was described as in full remission.

\section{Discussion}

Lymphomas are a heterogeneous group of cancer in terms of their morphologies and clinical features. This has affected their classifications and different classification systems have been used until now. ${ }^{1}$ Nowadays, the commonly used system is the one that was rearranged in 2008 by the World Health Organization (WHO) which classified it by considering all characteristics of hematopoietic-lymphoid tissues. ${ }^{2}$ Since the classification of WHO is complicated its clinical usage is difficult. Especially Non-Hodgkin's lymphomas are divided into two groups as the ones with a slowly progressive course and the ones with a rapidly progressive course in daily practice. ${ }^{1}$

A significant increase in the general incidence of lymphoma is underlined in the second half of the $20^{\text {th }}$ century. ${ }^{2}$ The fact that women get married late and have babies late increases the number of cases with co-existence of cancer and pregnancy. Only one out of a thousand pregnancies are associated with cancer. ${ }^{6}$ Lymphoma is rarely seen during pregnancy. Hodgkin's lymphomas are more common than Non-Hodgkin's lymphomas. ${ }^{3}$ Lymphoma is generally diagnosed late during pregnancy. ${ }^{7}$

Hormonal and immunologic changes play an important role in the course of lymphoma. In literature, a publication including a case series with 21 patients reported that lymphoma progressed during the first and partially second trimester and became stable until delivery. The tumor had a rapidly progressive course during the postpartum period. ${ }^{7}$

Diffuse large B-cell lymphoma is more aggressive and its complications may threaten life in the early period. As its prognosis is bad and it rapidly progresses it must be treated with a combination chemotherapy regimen. ${ }^{8}$

The most important finding in Non-Hodgkin's lymphoma is painless lymph node enlargement and diagnosing may also cause delays. ${ }^{1}$ While stretched, erythematous, warm, fluctuant, painful, tender, mobile, and soft 
lymphadenopathy suggests infection the lymph nodes with an elastic, firm, fixed, and painless enlargement mostly suggest malignancy. If bleeding, rapid growth, necrosis, and infections occur in tumor tissue, it may be lymphadenopathy. ${ }^{9}$ Lymph nodes up to $1 \mathrm{~cm}$ in axillary and cervical regions, $1.5 \mathrm{~cm}$ in inguinal regions, and $0.5 \mathrm{~cm}$ in epitrochlear regions are normal. ${ }^{10}$ In this case, painful lymphadenopathy was realized with systematic examination performed during the presentation to the family physician with upper respiratory tract complaints at the $17^{\text {th }}$ week of pregnancy, and an empirical therapy compatible with the therapy algorithm was initiated. When the patient was called for follow-up after the therapy she still had pain and the size of lymphadenopathy was greater than $1 \mathrm{~cm}$. The patient was referred to an otorhinolaryngology outpatient clinic for further examination and therapy because the size of lymphadenopathy became greater than $1 \mathrm{~cm}$ although she had painful lymphadenopathy.

As the patient was pregnant and diagnosed with malignancy a psychologically difficult situation to manage occurred. The family physician assessed the patient both psychologically and physiologically. Knowing that she had lost her baby before in her medical history, the family physician decided together with the patient and referred her to a psychiatrist so that she could get psychological support.

Family physicians can know the detailed medical history of the patients and perform their medical screening and follow-ups. Suspecting malignancy is the most important step in helping the physician to diagnose the disease and it should be kept in mind that malignancy can also be seen during pregnancy. Referring to a patient with a preliminary diagnosis of malignancy in a period when lymphomas are very rare such as pregnancy reveals how important and effective role the family physicians have in diseases in which early diagnosis is of vital importance. Moreover, with this case report, we can understand how important and effective the biopsychosocial support of family physicians is in diseases that are psychologically difficult to manage such as malignancies. 


\section{References}

1. Ferhanoğlu B, Meltem Olga A. Lenfoma Tanı Ve Tedavi Kılavuzu; 2018.

2. Soysal T. HematoLog. Türk Hematoloji Derneği 2013;3(2):253-70.

3. Macfarlane GJ, Evstifeeva T, Boyle P, Grufferman S. International patterns in the occurrence of Hodgkin's disease in children and young adult males. Int J Cancer. 1995;61(2):165-169. doi:10.1002/ijc.2910610204

4. Beksaç M. No Title. In: Maternal Fetal Tıp ve Perinatoloji. nobel; 2001:733.

5. Ioachim HL. Non-Hodgkin's lymphoma in pregnancy. Three cases and review of the literature. Arch Pathol Lab Med. 1985;109(9):803-9. http://www.ncbi.nlm.nih.gov/pubmed/3896191. (Accessed June 19, 2020).

6. Karadağ B. Gebelik ve Jinekolojik Kanserler: Literatürün Gözden Geçirilmesi. Türk Jinekolojik Onkoloji Dergisi. 2013;16(4):7-12.

7. Dasan J, Littleford J, McRae K, Farine D, Winton T. Mediastinal tumour in a pregnant patient presenting as acute cardiorespiratory compromise. Int J Obstet Anesth. 2002;11(1):52-6. (doi:10.1054/ijoa.2001.0915).

8. Koren G, Lishner M. Cancer in Pregnancy and Lactation: The Motherisk Guide. Cambridge University Press; 2011. (doi:10.1017/CB09780511794995).

9. Aydoğdu S, Yılmaz TG, Tuğcu D. Approach to Lympadenopathy: Case Report and Literature Review. Tuberculin Ski Test Child. 2016;15:118-23. (doi:10.5222/j.child.2015.118).

10. Çeçen E. Çocukluk çağı periferik lenfadenopatileri. AMÜ Tıp Fakültesi Dergisi 2009;10(1):45-52. 